\title{
Menopause and hormone replacement therapy
}

\author{
Ali Baziad
}

\begin{abstract}
Abstrak
Jumlah populasi pada abad ke-21 mencapai 6,2 milyar orang, pada tahun 2025 diperkirakan berkisar sekitar 8,3-8,5 milyar orang, dan jumlah ini akan terus meningkat. Kelompok usia lanjut diperkirakan akan tumbuh dengan cepat dibandingkan kelompok yang lain. Peningkatan secara cepat populasi usia lanjut terutama dijumpai di daerah Asia. Usia harapan hidup meningkat tajam di negara maju maupun di negara berkembang. Pada kebanyakan wanita menopause, peningkatan usia harapan hidup akan disertai dengan berbagai macam masalah kesehatan. Konsekuensi kekurangan estrogen adalah gejala menopause. Pengobatan keluhan yang berhubungan dengan menopause maupun penyakit telah menjadi isu kesehatan maupun sosial ekonomi yang sangat penting. Gejala jangka panjang seperti patah tulang akibat osteoporosis, penyakit kardiovaskuler, dan demensia, telah menimbulkan beban keuangan yang besar baik terhadap pasien secara individu maupun masyarakat umum. Terapi sulih hormon (HRT) alami sangat diutamakan. Estrogen sintetik yang biasanya terdapat di dalam kontrasepsi oral tidak dianjurkan sebagai terapi sulih hormon. Banyak kontra indikasi untuk kontrasepsi oral, tetapi sekarang kontrasepsi oral menjadi salah satu pilihan untuk terapi sulih hormon. Alasan tersering untuk tidak melanjutkan terapi sulih hormon adalah perdarahan yang tidak diinginkan, takut akan kanker, dan efek samping yang lain. Hingga kini masih ada perdebatan tentang hubungan antara terapi sulih hormon dengan kejadian kanker payudara. Banyak data tidak menunjukkan hubungan yang jelas antara penggunaan HRT dan kanker payudara. Karena itu, banyak ahli menyarankan penggunaan terapi sulih hormon, mulai saat pertama keluhan klimakterik muncul sampai meninggal. (Med J Indones $2001 ; 10: 242-51)$
\end{abstract}

\begin{abstract}
The global population in the $21^{\text {st }}$ century has reached 6.2 billion people, by the year 2025 it is to be around 8.3-8.5 billion, and will increase further. Elderly people are expected to grow rapidly than other groups. The fastest increase in the elderly population will take place in Asia. Life expectancy is increasing steadily throughout developed and developing countries. For many menopausal women, increased life expectancy will accompanied by many health problems. The consequences of estrogen deficiency are the menopausal symptoms. The treatment of menopause related complaints and diseases became an important socioeconomic and medical issue. Long term symptoms, such as the increase in osteoporosis fractures, cardio and cerebrovascular diseases and dementia, created a large financial burden on individuals and sociery. All these health problems can be treated or prevented by hormone replacement therapy (HRT). Natural HRT is usually preferred. Synthetic estrogen in oral contraceptives (oc) are not recommended for HRT. Many contra-indications for oc, but now it is widely used for HRT. The main reasons for discontinuing HRT are unwanted bleeding, fear of cancer, and negative side effects. Until now there are still debates about the relationship between HRT and the incidence of breast cancer. Many data showed that there were no clear relationship between the use of HRT and breast cancer. Therefore, many experts advocate the use of HRT from the first sign of climacteric complaints until death. (Med J Indones 2001; 10: 242-51)
\end{abstract}

Keywords: estrogen deficiency, climacteric phases, tibolone.

The human race entered the $19^{\text {th }}$ century with a global population of 978 million people, in the $20^{\text {th }}$ century with 1650 million people, and will enter the $21^{\text {st }}$ century with a worldwide population of 6168 million. ${ }^{1}$ The Growth was relatively slowed down during the first half of the $20^{\text {th }}$ century, so that global population was just barely above 2.5 billion in the year 1950;

Department of Obstetrics and Gynecology, Faculty of Medicine, University of Indonesia/Dr. Cipto Mangunkusumo General Hospital, Jakarta, Indonesia however, growth then accelerated and the world population reached 3700 million in 1970 , and 5630 million in $1994{ }^{1}$

The United Nations projects that humankind will enter $21^{\text {st }}$ century with a global population of 6.2 billion people. The rapid growth rate will continue for some time, and by the year 2025, the world population is projected to be around $8.3-8.5$ billion people. It is projected that the growth rate will slow down after 2025 , and even more so after the year 2075 , so that global population in the year 2100 
should be around 11.2 billion, and in 2150 perhaps 11.5 billion people.

The subgroup elderly and "old old" people of world population are expected to grow more rapidly than other subgroups. ${ }^{2}$ The expression "elderly" denotes people aged 65 years and over, and "old old " indicates people aged 80 years and over. ${ }^{3}$ During the 30 years between 1990 and 2020, the global population is expected to increase by $52 \%$, but its elderly population will increase by $115 \%$, and its "old old" population by $134 \%{ }^{4}$

The fastest increase in the elderly population will take place in Asia. The elderly population of Sweden and of the United Kingdom is expected to increase by 33 and $45 \%$, respectively; the corresponding increase in a number of Asian countries will be between 200 and $400 \% .{ }^{4}$ The "old old " population will double in Europe and triple in Asia, between 1990 and $2025{ }^{4}$

On the world, increase in life expectancy will follow the improvements in living standard. Life expectancy is increasing steadily throughout developed and developing countries. Between 1950 and 2050, life expectancy for men and women is projected to increase by more than 29 and 31 years, respectively. This indicates a global increase of $65-66 \%$ in life expectancy during the above period.

The average life expectancy of women in the United States has increased. In 1900 the average woman lived to the age 48 . Today, the average life expectancy is 80 years and the average age of menopause is $51{ }^{4}$ This means that women spend more than third of their life beyond menopause. ${ }^{5,6}$ In Indonesia, life expectancy in year 1980 was 50.9 years, whereas in 1990 it was increased to 62.7 years, and in year 2000 it is expected to be 70 years. ${ }^{?}$

Menopause means the last period of the cessation of normal menstruation, and can occur either physiological or artificially. It should be regarded as a hormone deficient state. In the next 2 decades, nearly 40 million women will pass through menopause. ${ }^{8} \mathrm{An}$ analysis of the distribution of postmenopausal women revealed that $40 \%$ lived in the industrialized world. It is predicted that the total number of postmenopausal women in 2030 will be approximately 1200 million, and the proportion of those living in the developing countries will increase $70.6 \%$. $^{9}$ In year 2025 , the number of Indonesian menopausal women will be approximately $35,000,000$ people. $^{10}$

The decrease in estrogen that is associated with menopause is accompanied by many physical changes, both short-term and long-term. Many of the early changes are associated with vasomotor instability, manifested by hot flushes and night sweats. Some $85 \%$ of women experience hot flushes at the time of menopause, and they are the most common reason for women to seek medical attention at this time. ${ }^{11,12}$ However, it is the long-term consequences of estrogen loss that represent the most significant concern in terms of disease.

Actually, menopausal women are still potential and useful for the development of their country. They still can work as consultant, teacher, trader, etc. However, long life doesn't mean happiness. A happy birthday song will be heard as a discordant song, if they are suffering in their old age.

The aim of this review is to describe the menopausal problems in general, and the role of HRT for the treatment and prevention of short- and long-term menopausal complaints due to estrogen deficiency.

\section{THE CLIMACTERIC - A PERIOD OF TRANSITION}

The climacteric is the period of transition from the reproductive phase of life to old age (senium). The word menopause is usually preferred, but this term is not accurate since menopause is a single event (the last menstruation), while the climacteric is a phase that can last for several years. The climacteric is subdivided into different phases (Figure 1). ${ }^{13}$

\section{The premenopause phase}

The premenopause phase is accompanied by minor endocrine changes. The serum concentration of FSH is higher than normal, whereas the level of LH remains unchanged, but the concentration of estrogen is still high during this premenopause phase. In premenopause phase, estrogen serum level has strong correlation with the climacteric symptoms, such as hot flushes and night sweats, and premenstrual symptoms, such as breast tenderness, bloating, irritability, and depressed mood. The premenopause phase usually begins at about 40 ; its end is determined by menopause. 


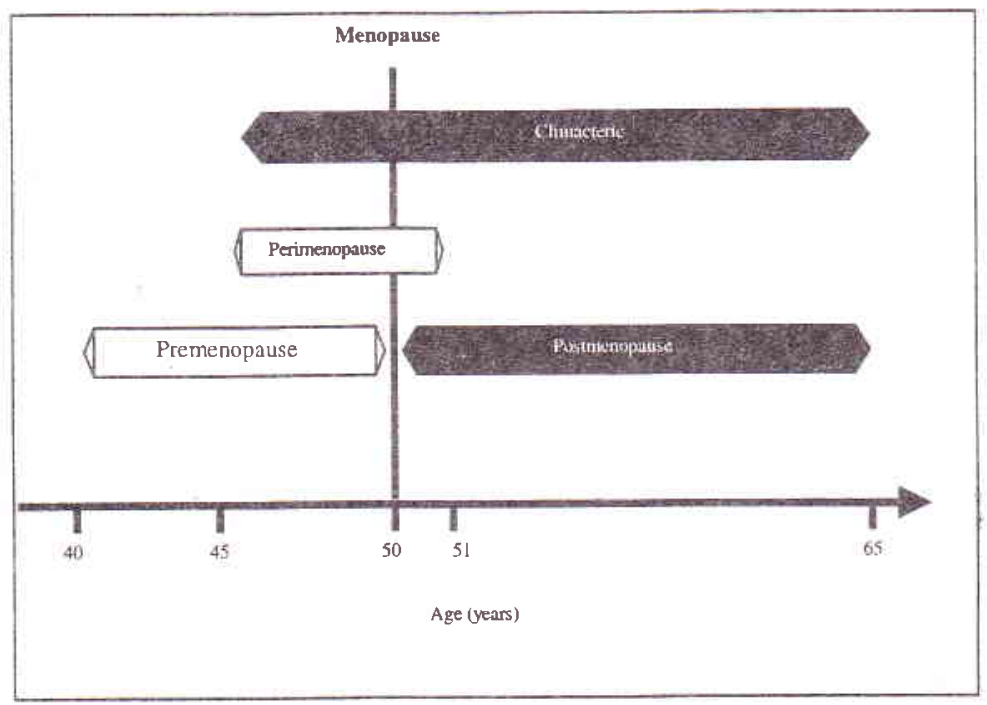

Figure 1. Climacteric phases and events. ${ }^{13}$

\section{The perimenopause phase}

The perimenopause begins with the onset of climacteric symptoms, and it ends one year after menopause. The menstrual cycle becomes irregular, and bleeding may last longer and become heavier. The FSH and LH level are not stable. It may be high, or low. Estrogen level may be so high, normal, and low as well. Many signs and symptoms generally associated with the postmenopause will manifest already during perimenopause. They include hot flushes, night sweats and vaginal dryness. In perimenopause phase, no correlations were found between estrogen level and the vasomotor symptoms. Even hot flushes happen, in the higher estrogen level. Until now, there is no explanation why high estrogen is able to induce the vasomotoric complaints.

\section{Menopause and postmenopause}

The term menopause is derived from the Greek words for month and end, and refers to the cessation of menstrual periods. The increased rate of atretic follicles, significantly reduces the number of oocytes or follicles in the ovaries, the ovaries can no longer produce mature follicles and sex hormones. Reproductive capability ends with menopause.

Postmenopause is the last phase of transitional period: it starts at menopause and ends when the senium begins at age 65 . The irregular secretion of sex hormones ceases at menopause, and the endocrine pattern in the postmenopause differs completely from that in fertile phase of life. The primary cause of the changes is the almost complete cessation of follicular development in the ovaries, and the resulting low production of estrogen, and the drastic increase in the serum concentration of FSH and LH (Figure 2). ${ }^{13}$

\section{THE MENOPAUSE AND ITS CONSEQUENCES}

The consequences of the drop in estrogen levels are the menopause symptoms. The symptoms can happen as short, medium, long, and very long term symptoms. Short-term symptoms are classic symptoms, such as heavy and irregular bleeds, and vasomotor disturbances (e.g. hot flushes, sweats, and palpitation). Mediumterm symptoms are atrophic vaginitis, dyspareunia, incontinence, and recurrent urinary tract infection. Long-term symptoms are osteoporosis and its consequence (bone loss/osteoporotic fractures), cardio and cerebrovascular disease, colon cancer, and tooth loss. Very long-term symptom is Alzheimer's type dementia.

In addition, a large number of other somatic and psychological complaints are often reported by women in the climacteric years, and these complaints are called atypical climateric symptoms. In the case of these atypical climacteric symptoms, the link with decreased estrogen level is not always clear, ${ }^{14}$ (Table 1). ${ }^{14,15}$ The symptoms are presumed to be psychological and sociocultural in origin. 


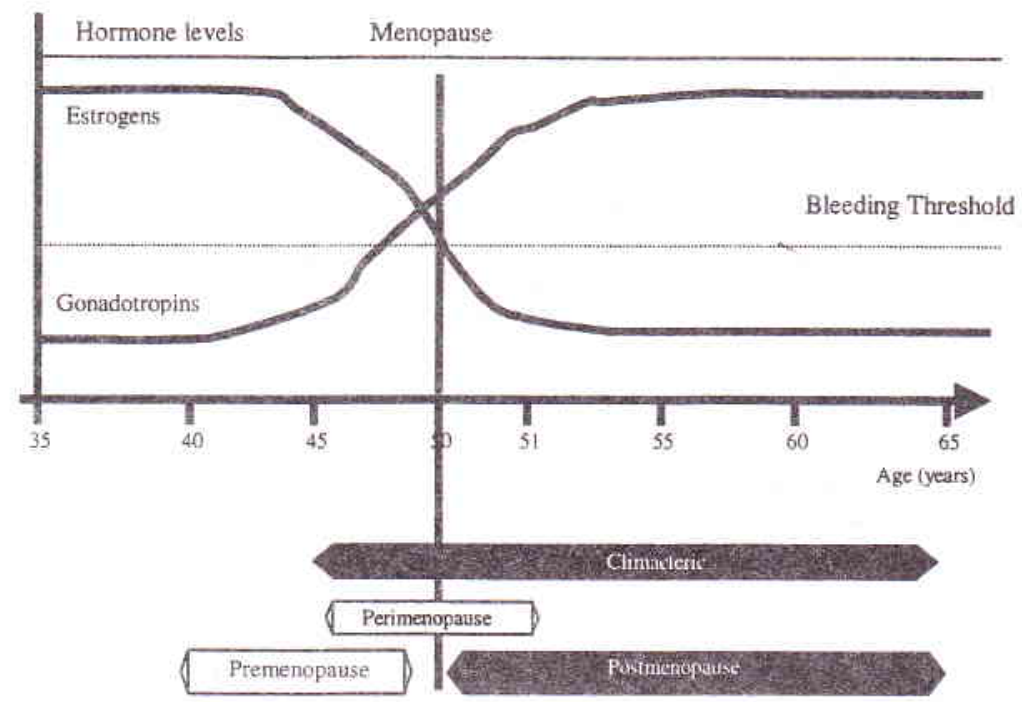

Figure 2. Changes in sex hormone concentrations. ${ }^{13}$

Table 1. 'Atypical ' climacteric complaints ${ }^{14,15}$

Feeling tense
Muscle/joint pain
Tiredness
Tired on waking
Lack of self-confidence
Insomnia
Forgetfulness
Restless legs
Irritability
Headache
Depression

Dizziness

Pins and needles

Lack of energy

Shortness of breath

Vaginal dryness

Itching labia

Migraine

Lost of urine

Vaginal discharge
Headache

\section{HORMONE REPLACEMENT THERAPY (HRT)}

Because of the large and still increasing number of peri and postmenopausal women, the treatment of menopause related complaints and diseases becomes an important socioeconomic and medical issue in the industrialized countries, and it will be soon so in the developing countries as well. Long-term symptoms of estrogen withdrawal, such as the increase in osteoporotic fractures, cardio and cerebrovascular disease, and dementia, are associated with a large financial burden on individuals and the society. All these health problems can be treated or prevented by HRT.

\section{Indications}

Many climacteric symptoms are indication for HRT. Treatment or prevention of severe, long-term disorder such as osteoporosis, cardio or cerebro-vascular disease, dementia, colon cancer, tooth loss is a fairly recent indication. Hormone replacement therapy can also be given prophylactically to asymptomatic women, if they request HRT to prevent climacteric disorder or to reduce the risk of long-term disorder. The treatment can be given to all menopausal women even in obese patient. However, for an obese patient adjusting to a smaller dose is suggested.

The primary aim of HRT is to improve the physical and psychological well being of women who suffer from climacteric disorder, that is, to improve their quality of live.

\section{Hormones used in HRT}

Different estrogen molecules are available for HRT. In contrast to hormonal contraception, natural estrogen are usually preferred in HRT. Natural estrogens are those that are chemically identical to the estrogen biosynthesized in the human body. Thanks to modern technology, estradiol (E2) - the most potent human estrogen- can be manufactured synthetically 
with high quality and purity. The currently available preparations of E2 contain a synthetic natural estrogen.

The synthetic estrogen, ethinylestradiol - the most frequently used estrogen in oral contraception (OC) and its related compound such as mestranol are far more potent than the natural estrogen estradiol. This potency produces unwanted side effects, especially activation of the liver, which increase the synthesis of certain blood clotting agents, and increased angiotensinogen 350 times stronger than natural estrogen. ${ }^{16}$ Because of this side effect, ethinylestradiol is no longer recommended for HRT.

Natural estrogens, in the form of conjugated estrogens, estradiol valerate and micronized estradiol are widely used estrogens. Conjugated estrogens are derived from the urine of pregnant mares. The other natural estrogen, estriol (E3), and estriol succinate are mainly used for the treatment of urogenital atrophy, because of its biological activity that is too low to prevent osteoporosis or cardiovascular disease.

Progestogens are generally used as opponents of estrogen to protect the endometrium from hyperplasia. Natural progesterone, such as medroxyprogesterone acetate (MPA), cyproterone acetate, and dydrogesterone are the most widely used in combined HRT. The synthetic progesterone which is testosteronederived often displays a distinct androgenic effect, such as acne, fluid retention, disturbed glucose metabolism, liver dysfunction, and changes in blood clotting.

The use of combination of estrogen and androgen is not so common. Even though, some experts use this combination mainly for improving the severe libido disturbances. ${ }^{17}$ For preventing either addiction or masculinization effects, it is suggested to use DHEA which is a natural androgen.

An exceptional C-19 steroid is tibolone. This substance exerts both estrogenic and progestogenic, as well androgenic effects.

\section{Routes of administration}

The most frequent route is oral administration. Oral administration has several advantages, such as: treatment can be stopped, or the dosage can be decreased on a daily basis in cases of adverse effects. In addition, if the original dosage is not effective, it also can be increased quickly. It is better to take this drug after meal, in order to keep the serum hormonal level remains stable for a long time. The food will stimulate gall bladder activity, and increase the secretion of conjugated estradiol into gall bladder. From the gall bladder, estradiol will continuously enter intestine for hydrolysis, and is absorbed again into blood serum.

Injectable estrogen preparation is available, for example one injection per month. Estrogen can also be administered as subcutaneous implants. Special caution in using either injectable or implant for patient with intact uterus should be taken, as it may cause heavy bleeding.

Another type of administration is the transdermal patch, which is placed on the skin and gradually releases an estrogen, or an estrogen and progestogen, into the circulatory system. Dermal creams are another type of percutaneous application, but patches are now much more popular; skin irritation is the only specific, though infrequent, side effect. ${ }^{18}$

Another route is topical administration at the target site. Vaginal estrogen creams were originally used for the management of local symptoms, like atrophic vaginitis and vulvitis. Most topical preparations contain the biologically weakest estrogen, estriol (E3). Topical estrogens are also readily absorbed through the vaginal wall and, if E2 is used, it results in a physiologic estrogen balance in the general circulation, but at transient supraphysiologic concentrations. As with the other routes, a progestogen must also be given to nonhysterectomized women.

\section{Replacement regimens}

Although the types of treatment regimen vary according medical requirements, and also from country to country, one universal consensus has been reached: estrogen monotherapy, whether cyclic or continuous, is indicated only in hysterectomized women to avoid the risk of endometrial hyperplasia in women with an intact uterus (Figure 3).

Current expert consensus is to treat women with an intact uterus with estrogens and a progestagen. The cyclic sequential combination with a treatment-free interval is the most recommended type of combination therapy in perimenopausal women. The patient takes estrogen for 21 consecutive days, accompanied by a progestogen for the last $10-13$ days. A similar type of HRT is the sequential combination without a treatment -free interval. 

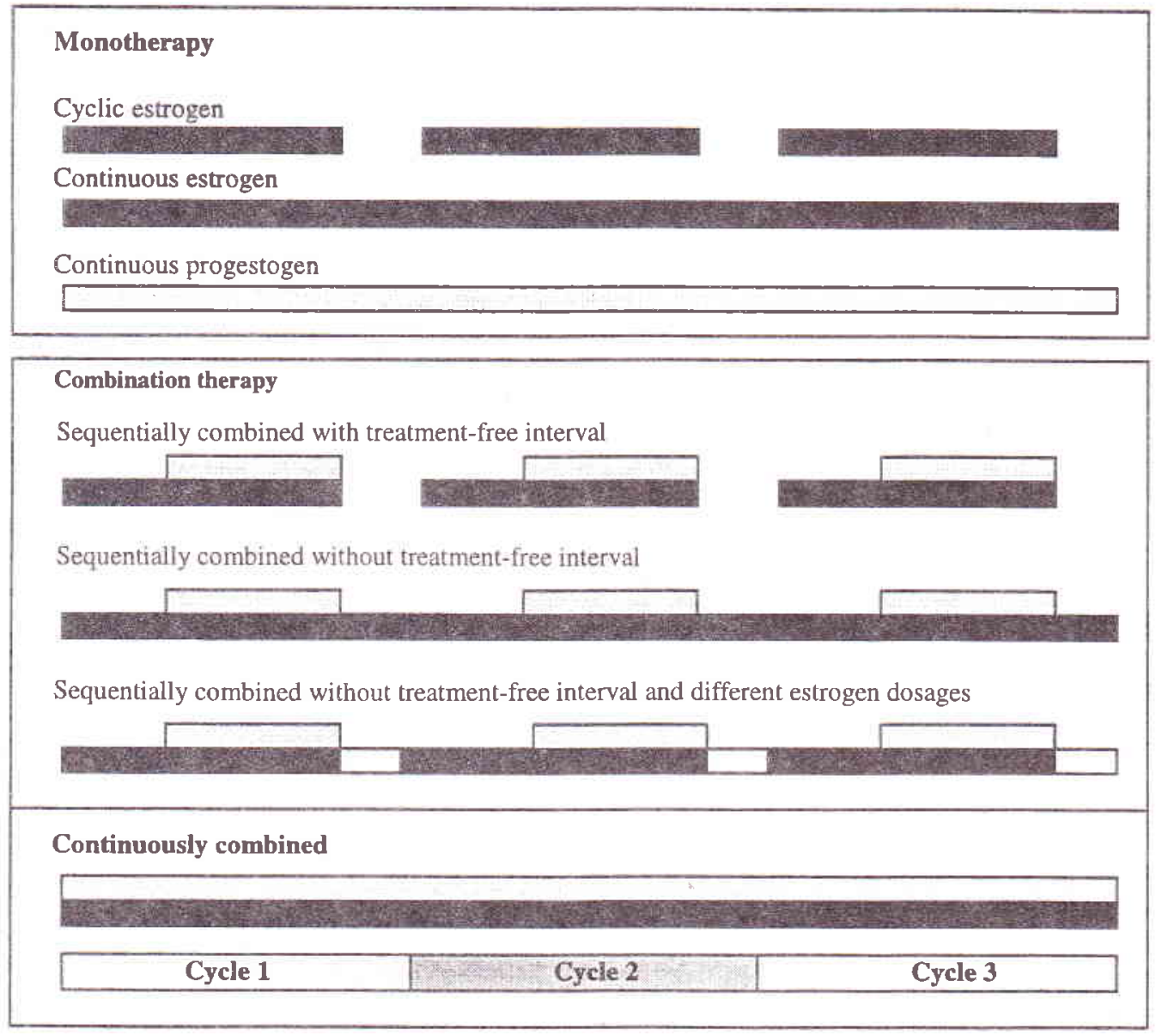

Figure 3. Hormones replacement therapy regimes ${ }^{13}$

The cyclic addition of a progestogen usually leads to withdrawal bleeding. However, many women who start using HRT several years after menopause regard the resumption of regular bleeding as a disadvantage of HRT, making it the one of the main reasons for discontinuation of treatment. To avoid regular bleeding and to achieve complete amenorrhea, continuous combination therapy, especially in postmenopausal women, is recommended.

\section{Contra-indications for HRT}

Contra-indications for estrogen therapy are: a history of breast cancer, a history of endometrial cancer, serious liver dysfunction, and porpyria.

Conditions in which HRT is not contra-indicated are: prolactinoma, malignant melanoma, liver adenoma, varices, diabetes mellitus, otosclerosis, hyperthyroidism, sickle cell anemia, endometrial hyperplasia, hypertension, myocardial infarction, and history of stroke.

\section{Cultural differences}

Several aspects of the menopause are universal, shared by all women from all parts of the globe. This does not mean that all women have their menopause at around the age of 50, the traditional age given for modern Western women. The range of menopausal ages is quite varied, culture-to-culture. We do not know yet whether this is due to genetic or environmental factors, both physical and cultural, or to methodological differences in attaining this age. In Indonesia (central Java), the menopausal age is 50.2 in educated women, and 46.0 in rural area, ${ }^{19}$ in Karachi, Pakistan $47.0{ }^{20}$ in Netherlands $51.4,{ }^{21}$ and in United States - Massachusetts 51.3. 
A number of investigators have focused on the situations in particular countries of the East Asian region as counterparts to the Western world. A study conducted in menopausal women in seven South-East Asian countries revealed a median age at menopause of 51.09 years, which appeared to be within the range observed in Western countries. ${ }^{22}$

Another global aspect of menopause is the physiological dimension of this event. In Europe and the USA, the women most bothered by the climacteric are those in the lower socioeconomic classes. In Asia, the situation is exactly the opposite, severe symptoms were reported frequently by women in the higher socioeconomic classes. $^{23}$ A retrospective study including 1056 higher socioeconomic women in Jakarta in year 1998 demonstrated that $35 \%$ women suffer from hot flushes. ${ }^{24}$ In general, climacteric symptoms (flushes and sweats) are more common in European and North American women than in other population.

A high intake of dietary phyto-estrogens among women in some developing countries may play an important role in reducing the consequences of estrogen deficiency. This has been suggested as'a possible explanation, not only for the lower frequency of menopausal symptoms, but also for the lower rate of breast cancers and hip fractures in Japanese compared with Caucasian women. Soya is consumed in large quantities in Japan and contains precursors of the weak estrogenic isoflavones, genistein and daidzein. The Japanese daily diet contains about 80 mg of genistein; which is about 80 times greater than in the typical daily American diet.

There are enormous differences in risk of atherogenic cardiovascular disorder between cultures. Western society and in the USA, cardiovascular disease (CVD) are by far the most common cause of death in women over the age $65 .{ }^{25}$ But now the situation has already changed. Several Asian countries have experienced rapid socioeconomic changes over the last two decades. Daily caloric intake has increased. In China and India alone, 4.5 - 5 million people die each year from cardiovascular disease. In China, the mortality rate attributable to CVD increased from 86.2 per 100,000 in 1957 (12.1\% of total deaths) to 214.3 per 100,000 in 1990 ( $35.8 \%$ of total deaths) in urban areas (American Heart Association. Biostatistical fast sheet - population. International cardiovascular disease statistics. Internet communication, 1990).
Although many short term and long term menopause disorders can be treated or prevented by hormone replacement, only a minority of climacteric women are treated with HRT. Even in countries with high acceptance rates-the United States and Germany, for examples- only about one-quarter of women between ages 45 and 64 use HRT. In other countries, for example, Brazil or Italy, the rate currently does exceed $5 \% .^{13}$ Acceptance rates differ not only from country to country, but also among regions within countries. In Finland, for example, $30 \%$ of the women in Helsinki, the capital city, use HRT preparations, but only $15 \%$ of those in rural areas use them. ${ }^{13}$ In a retrospective study conducted in a capital city Jakarta in year 1998, from 1054 menopausal women between 45 and 69 years, only $15 \%$ used HRT.

The average use of HRT is short duration. In a study in a number of general practices in London, the average length of HRT usage was 21 months, with a median duration of 11 months. ${ }^{26}$ Other studies showed similar results such as $72 \%$ continued beyond 8 months, and $15 \%$ continued beyond 2 years. ${ }^{27,28}$ In one retrospective study conducted in 1998 in Jakarta, Indonesia, $62 \%$ of menopaused women used HRT for one year, $18 \%$ for 2 years, and $12 \%$ for 3 years. ${ }^{24}$ Thousand and fifty six menopausal women were included in this retrospective study. The main reasons for discontinuing HRT are unwanted bleeding, fear of cancer, and other negative side effects. ${ }^{24,27}$ Beside the women itself, also doctors are still afraid to prescribe HRT for their patients. The main reason is fear of breast cancer (Table 2).

Table 2. Reasons for discontinuing HRT ${ }^{24}$

\begin{tabular}{lc}
\hline \multicolumn{1}{c}{ Reasons } & Percentage \\
\hline Gynecologist & 49 \\
Other specialist & 15 \\
General practitioners & 11 \\
Breast cancer & 15 \\
Bleeding & 6 \\
Boring & 3 \\
Cost & 1 \\
\hline
\end{tabular}

In the past, other reasons why physician fears to prescribe HRT are too many contraindications. However, recently, several contra-indications such us diabetes mellitus, hypertension, stroke, and CVD, that are still the contraindications for $\mathrm{OC}$, are not regarded 
as contraindications for HRT anymore. The reason for this is that OC contains synthetic steroid, whereas HRT contains natural steroid.

To achieve optimal compliance with any drug regimen both the physician and the patient must accept the therapy, and must have more knowledge of HRT. It has been shown that patient compliance with HRT can be enhanced, if the physician explains the purpose, risk, and side effects of this treatment properly. Several reviews emphasized the importance of education and information for the patient. So, information for the women is the cornerstone of success.

\section{Vaginal bleeding episodes associated with HRT}

Vaginal bleeding is a common concern to HRT users; it has major impact on compliance, and termination of treatment. ${ }^{29}$ In approximately $95 \%$ of current users, sequential combination HRT regiment will induce withdrawal bleeding at the end of each cycle, and only about $6 \%$ of users experience no bleeding. ${ }^{30}$

In the case when woman doesn't want to get withdrawal bleeding, physician should give continuously combined HRT. Continuous HRT or the use of other compounds (e.g. tibolone) has been advocated to overcome the scheduled withdrawal bleeding associated with sequential combination HRT. ${ }^{31}$ The bleeding like spotting can occur during the first three months. ${ }^{32}$ The incidence of such bleeding decreases rapidly within the first year of treatment. Once amenorrhoea is achieved, the endometrium will remain inactive in most women.

In several Moslem countries, the bleeding during HRT will give a big problem. They believe, that bleeding will harm their praying. They may not be able to differentiate between bleeding and menstruation. If the menstruation occurred, they would be prohibited to pray, but in case of bleeding, pray is not prohibited. Therefore, in many Moslem countries, continuously combined HRT is more acceptable than sequential combined HRT. ${ }^{33}$

Heavy bleeding is usually caused by high estrogen and low progestogen dose, and spotting is caused by high progestogen dose. To treat such bleeding is very simple. By increasing or reducing the dose of steroid, normally the bleeding will stop. If the bleeding is left untreated, it will lead to poor compliance.

\section{Breast cancer and HRT}

One of the most controversial aspects of hormone therapy is its possible association with an increase risk of breast cancer. Until now it is still in debate about the relationship between HRT and the incidence of breast cancer. Use of HRT for more than 5 years was recently associated with a $40 \%$ increase in the risk of developing breast cancer. $^{34}$ Other investigator concluded that there was no real increase in relative risk of breast cancer in estrogen users. ${ }^{35}$ Collaborative reanalysis of data from 51 epidemiological studies involving 52,705 women with breast cancer and 108,411 women without breast cancer showed that the diameter of the tumors were smaller, and metastases to lymph node was rare. This indicated that HRT had no influence on the receptor in breast. ${ }^{36,37}$ Prospective study on 420,000 postmenopausal women using HRT showed no increase in mortality rate caused by breast cancer. ${ }^{38}$

Over 50 studies have examined the relationship between ERT/HRT and breast cancer. These studies also showed no clear trend in regard to such an association. ${ }^{35,39}$ One long-term prospective double blind study that investigated breast cancer and estrogen found no increase in breast cancer in women with estrogen therapy. None of the estrogen treated women ( $2.5 \mathrm{mg}$ of conjugated equine estrogens po qd and MPA $10 \mathrm{mg}$ po gd for 7 days per month) developed breast cancer. ${ }^{40}$

Most doctors and patients still believe, that cancer history in family is a contraindication or a risk factor for hormone replacement therapy. There is little evidence to support the common perception that family history of breast cancer is a contraindication for HRT. A recent study found that there was no significant increase in breast cancer among hormone users. $^{41}$ There was, however, a significant reduction in total mortality.

Using HRT after breast cancer diagnosis, though contraindicated, remains controversial. After a diagnosis of breast cancer has been made, a women or her physician should review the currently available data to make a decision. There are no clinical studies showing that HRT increased the rate of relapse among women who have had breast cancer. Overall, ERT does not seem to affect survival after the diagnosis of breast cancer, and hormone therapy may improve the patient's quality of life. Recent data suggest that when estrogen is given to women with a past history of 
cancer (who are operated on breast cancer previously), a lower rate of recurrence occurred, compared to women with breast cancer, who do not receive estrogen. ${ }^{42}$ The patients who worry about the correlation between breast cancer and HRT, may be given selective estrogen receptor modulator (SERM).

\section{How long should women take HRT?}

No consensus has yet been reached on long term HRT. Many experts advocate the use of HRT until 5 or 10 years after menopause in order to postpone the onset of cardiovascular disease, osteoporosis, dementia, and colon cancer. ${ }^{16,43}$ Another proposal is to use hormones from the first sign of the climacteric -or, in symptomatic women, from the time menopause is ascertained-until death. ${ }^{13}$ The advantage of lifetime HRT is the reduced risk of long-term consequences. The decision to use hormones over longer period of time must be based on an assessment of the benefits and risks.

\section{CONCLUSION}

For many menopausal women, increasing life expectancy will be accompanied by many health problems. The consequences of estrogen deficiencies are the short and long term symptoms. Short and long term symptoms are the most reasonable indication for HRT. Despite the increasing evidence of cardiovascular protection and prevention of osteoporosis, cardio and cerebrovascular disease, colon cancer, tooth lost and dementia in women using HRT, there is still a concern about its relationship with breast cancer. Many prospective studies on postmenopausal women using HRT showed no increase in mortality rate caused by breast cancer. The decision to use HRT over longer period of time must be based on assessment of the benefits and risks.

\section{REFERENCES}

1. United Nations Department for Economic and Social Information and Policy Analysis. Population Division. World population prospects; the 1994 revision. Document ST/ESA/SER/A/145. New York: United Nations, 1995.

2. Diczfalusy $\mathrm{E}$, Banagiano $\mathrm{G}$. Women and the third and fourth age. Int J Gynecol Obstet 1997;58:177-88.

3. Diczfalusy E. The third age, the third world and the third millennium. Contraception 1996;53:1-7.

4. World Health Organization. Epidemiology and prevention of cardiovascular disease in elderly people. WHO Tech Rep Ser, Geneva: WHO, 1995.
5. Burnett RG. Menopause : All your questions answered. Chicago : Contemporary Books, 1987.

6. Soules MR, Bremmer WJ. The menopause and climacteric: endocrinologic basis and associated symptomatology. J Am Geriar Soc 1982;30:547-61.

7. Baziad A, Sedyawan J. Menopause, hormone replacement therapy, and cardiovascular disease. In: Baziad A, Lazuardi S, Dharmasetiawan S. Around menopause. Jakarta: Medical School University of Indonesia, 1995. p.5-9.

8. Skoinick AA. At third meeting, menopause experts make the most of insufficient data. JAMA 1992;268:2483-4.

9. Diczfalusy E. Growing rapidly and ageing rapidly, or the tyranny of numbers. In: Ratnam SS, Campana A, eds. First consensus meeting on menopause in the East Asian Region. Geneva: Medical Forum International, 1998. p.11-22。

10. Baziad A, Sedyawan J. Menopause, hormonal replacement therapy and coronary heart disease. In: Baziad A, Lazuardi S, Darmasetiawan M. Around menopause. Jakarta: Organon Indonesia, 1995. p.5.

11. Oldenhave A, Jaszmann LJB, Haspels AA. Impact of climacteric on well-being: A survey based on 5213 women 39 to 60 years old. Am J Obstet Gynecol. 1993;168:772-80.

12. Judd HL, Meldrun DR. Physiology and pathophysiology of menstruation and menopause. In: Romney SL, Gray MJ, Little AB, eds. Gynecology and Obstetrics: The Health care of women. $2^{\text {nd }}$ ed. New York: McGraw, 1981. p.885-907.

13. Uwe Hollihn K. Hormone replacement therapy and the menopause. Fertility control and Hormone Therapy. Berlin: Schering, 1997. p.85-100.

14. Aso T. Demography of the menopause and pattern of climacteric symptoms in the East Asian Region. In: Ratnam SS, Campana A, eds. First consensus meeting on menopause in the East Asian Region. Geneva: Medical Forum International, 1998. p.24-31.

15. Reckers $H$. Mastering the menopause. In: Burger $H$, Boulet M, eds. A portrait of menopause: expert reports on medical and therapeutics strategies for the 1990s. Carnforth: Parthenon, 1991.p.23-43.

16. Khul H, Taubert HD. Postmenopausale Osteoporosis. In: Khul H, Taubert HD. Das Klimakterium. Stuttgart: Georg Thieme Verlag, 1987.p.291-322.

17. Hailes J, Brunger $\mathrm{H}$. Management of menopausal symptoms with estradiol-testosterone implants: clinical, biochemical and hormonal results. Maturitas 1984;6:124-5.

18. Sidabutar TP, Baziad A. Tolerance and acceptance of the use of Patch 17-beta Estrtadiol in postmenopausal women in Indonesia. Maj Obstet Ginekol Indones 2000;24:179-87.

19. Flint M, Samil RS. Cultural subcultural meanings of the menopause. Ann NY Acad Sci 1990;592:134-48.

20. Wasti SC, Robinson Y, Akhtar S, Kahn S, Badaruddin N. Characteristics of menopause in three sosioeconomic urban groups in Karachi, Pakistan. Maturitas 1993;16:6170.

21. Jaszman L, Van Lith ND, Zaat JCA. The age at menopausa in the Netherlands : the statistical analysis of a survey . Int J Fertil 1969;14:107-17. 
22. Boulet MJ, Odens BJ, Lehert P. Climacteric and menopause in seventh South - East Asian countries. Maturitas . 1994;19:157-76.

23. Flint M. Changes in sexual behaviour during middle age: a comparative study of American Jews, Indians and Indoesians. Data presented at the menopause congress. February 1990, Bangkok. Abstracts no.201.

24. Baziad A. A retrospective study of menopause women in private menopause clinic "Menox" Jakarta, from December 1996 to December 1999. In press.

25. Baziad A, Pache T. Cardiovacular disease and hormone replacement therapy. In: SS Ratnam, A Campana, eds. First consensus meeting on menopause in the East Asian Region. Geneva: Medical Forum International, 1997. p.105-19.

26. Spector TD. Use of oestrogen replacement therapy in high risk group in the United Kingdom. Br Med J 1989;299:1434-5.

27. Ryan PJ, Harrison R, Blake GM, Fogelman I. Compliance eith hormone replacement therapy (HRT) after screening for postmenopausal osteoporosis. Br J Obstet Gynaecol 1992;99: 325-8.

28. Barlow DH, Brockie JA, Rees CMP. Study of general practice consultations and menopausal problem. Br Med J 1991;302:274-6.

29. Hahn RG. Compliance considerations with estrogen replacement withdrawal bleeding and other factor. Am J Obstet Gynecol 1989;161:1854-8.

30. Gambrell RDJr, Bagnell CA, Greenblatt RB. Role cf estrogens and progesterone in the etiology and prevention of endometrial cancer:review. Am J Obstet Gynecol 1983;146:696-707.

31. Staland B. Continuous treatment with natural oestrogens and progestogens. A method to avoid endometrial stimulation. Maturitas 1981;13:145-56.

32. Mattsson LA, Cullberg G, Samsioe G. Evaluation of a continuous oestrogen-progestogen regimen for climacteric complaints. Maturitas 1981;4: 95-102.

33. Aswita I. Hukum Islam tentang pengunduran haid dan ibadah. Bandung: Almaarif, 1983.

34. Coldizt GA, Hankinson SE, Hunter DJ, Willet WC,
Manson JE, Stampfer MJ et.al. The use of estrogens and progestins and the risk of breast cancer in postmenopausal women. N Engl J Med 1994; 5:415-21.

35. La Vecchia C, Negri E, Franceschi S. Hormone replacement therapy and breast cancer risk: a cooperative Italian study. Br J Cancer 1995;72:244-8.

36. Collaborative group on hormonal factors in breast cancer. Breast cancer and hormone replacement therapy: collaborative reanalysis of data from 51 epidemiologycal studies of 52705 women with breast cancer and 108 411 women with breast cancer. Lancet 1997;350:104759.

37. Harding C, Knox WF, Faracher EB, Baildam A, Bundred NJ. Hormone replacement therapy and tumour grade in breast cancer : prospective study in screening unit. $\mathrm{Br}$ Med J. 1996;312:1646-7.

38. Willis DB, Calle EE, Miracle-Mc Mahill HL, Heath CW. Estrogen replacement therapy and risk of fatal breast cancer in prospective cohort of postmenopausal women in the United States. Cancer Causes Control 1996;7:44957.

39. Vassilopolou-Sellin R. Estrogen replacement therapyin women at increased risk of breast cancer. Breast Cancer Res Treat 1993;28:167-77.

40. Nachtigall MJ, Smilen SW, Nachtigall RH, Nachtigall RH, Nachtigall LE. Incidence of breast cancer in a 22 year study of women receiving estrogen-progestin replacement therapy: Obstet Gynecol 1992;80:827-30.

41. Sellers TA, Mink PJ, Cerhan JR. The role of hormone replacement therapy in the risk for breast cancer and total mortality in women with a family history of breast cancer. Ann Intern Med 1997;127: 973-80.

42. Vassilopolou-Sellin R, Zolinski C. Estrogen replacement therapy in women with breast cancer : a survey of patient attitudes . Am J Med Sci 1992;304: 145-49.

43. Fumer SE, Davis FG, Nelson RL. A case -control study of large bowel cancer and hormone exposure in women. 1997;8:4936-40. 